\title{
The Effect of Principal Leadership and Work Discipline on Teacher Performance at SMA PGRI 2 Palembang
}

\author{
Deslihanida $^{1 *}$, Yasir Arafat ${ }^{1}$, Yenny Puspita ${ }^{1}$ \\ ${ }^{1}$ Universitas PGRI Palembang, Indonesia \\ "Corresponding author.Email: deslihanidarusli@8505gmail.com
}

\begin{abstract}
The aim of this study was to determine whether the principal's leadership and work discipline had an effect on the success of the instructor. The study sample consisted of 67 SMA PGRI 2 Palembang teachers. The approach used is descriptive analysis and multiple linear regression techniques. The findings of the appraisal test indicate that: 1) there is a positive impact on Teacher Performance of the Principal Leadership. Since the value of t-count is 6.480 and the value of $\mathrm{t}$-table is 2,000 , i.e. the value of $\mathrm{t}$-count $>\mathrm{t}$-table, which means that Ha1 is approved Hol is rejected; (2) there is a positive effect of Work Discipline on Teacher Efficiency. Since the value of t-count is 5.808 and the value of $\mathrm{t}$-table is 2,000, in other words, the value of $\mathrm{t}$-count $>\mathrm{t}$-table, which means that $\mathrm{Ha} 2$ is approved Ho2 is rejected, and 3) there is a positive impact of the Principal Leadership and Work Discipline jointly on Teacher Efficiency. Because the value of F-count is 25,027 and the value of $>$ F-table is 3,150, this means that the value of F-count $>$ F-table, which means that Ha3 is accepted by Ho3, is rejected.
\end{abstract}

Keywords: Principal Leadership, Work Discipline, Teacher Performance

\section{INTRODUCTION}

The low quality of human capital is a fundamental challenge that can obstruct national economic growth and development. The creation of human capital must be followed gradually and consistently through a quality education system, both in formal, informal and nonformal education, starting from basic education to higher education [1]. Mulyasa also stressed the importance of establishing a quality education system that needs to be emphasized because numerous indicators indicate that current education has not been able to generate capital in line with the needs of community growth and development. Teachers are one of the most essential elements of education. Teachers have a broad and strategic role to play in the sense of education. This is attributable to the transition of information and technology, as well as to the education of positive values through guidance and exemplary [2].

This research is inspired by the findings of Ohide and Mbogo [3] in Sudan that leadership affects the satisfaction and success of teachers in any private primary school. The findings of research by Emmanouil et al [4] in Greece suggest that leadership policy is one of the main factors influencing the effectiveness of teachers. Several leadership policies activities have been shown to contribute to teacher empowerment.

Next, the findings of research conducted by Susanti, Harapan and Wardiah [5] show that: leadership style and work motivation together have a significant effect on the work discipline of Madrasah Aliyah in Polongbangkeng Regency.

Research by Ruslan, et al [6] finding the impact of the Principal's situational style of leadership on the performance of public elementary school teachers in Penuguan; the effect of teacher professionalism on the performance of public SD teachers in Penuguan; and the influence of the Principal's situational style of leadership and teacher performance is evident.

Herry et al research [7] has shown a positive influence between primary leadership and teaching contribution to the professional success of teachers at SMP PGRI 1 Palembang. Next, the research findings of Perawati et al [8] indicate that there is at the same time a major impact of pay, job motivation and discipline on the productivity of teachers at work. In their research Kartini et al [19] note that there is a major influence on the success of teachers between principal leadership, academic supervision and professional competence at 
the same time. The role of the Principal as a leader with a style of leadership must be able to influence other people or subordinates, must have strong emotional intelligence; and must have a high degree of job satisfaction [10].

According to the information collected, the performance of SMA PGRI 2 Palembang teachers in the performance of their jobs is not satisfactory, this is due to several reasons, among others; 1) there are still teachers who are not disciplined in the performance of their duties; 2) there are still teachers who have not mastered ICT; 3) there are still teachers who teach in a monotonous way; 4) there are still teachers who have not mastered ICT.

Mitriani [11] argues that success is a process tool to build a common understanding of what needs to be accomplished, how it needs to be achieved and how to coordinate people in a way that enhances the possibility of achieving goals. In the meantime, Suwarni [12] notes that the success of the teacher is the result obtained by the teacher in carrying out the tasks given to him on the basis of expertise, experience and sincerity. The effectiveness of schools in improving the standard of education is a joint responsibility between teachers and school principals [13]. Teacher output is said to be good if it involves elements of high loyalty and dedication to teaching tasks, mastering and creating teaching materials for other assignments, ingenuity in teaching execution, cooperation with all school stakeholders, leadership that becomes role models. Students, who have a strong personality, are truthful and impartial in directing students and are responsible for their duties. Successful teachers can also produce high-quality students [14].

Performance is simply what workers do or don't do. Performance management is all practices conducted to enhance the performance of a business or organisation, including the performance of each person in a company [15]. In addition, according to Kopelmen in Supardi [16], there are four factors influencing organizational efficiency, namely: 1) the environment, 2) individual characteristics, 3) organizational characteristics, 4) organizational characteristics. The level of success of the instructor can be assessed by indicators; 1) quality of work, 2) quantity, 3) speed/exactness of work, 4) capacity to work, 5) communication [17].

Leadership is a method of guiding the actions of others towards the achievement of such objectives. Path in this case, which means that other people have to behave in a way that follows a certain direction [15]. According to Wahyudi in Yuliana [2] leadership is the capacity of an individual to shift, guide, and influence the way of thinking, the working method of each member to be independent in working, in particular in making decisions with a view to accelerating the achievement of predetermined goals.
Discipline as an attitude or conduct and action in compliance with the rules laid down by the organization or entity concerned, both in writing and not in writing. Good work discipline represents the responsibility of an individual for the tasks assigned to him or her [18].

In addition, Jeffrey and Soleman [19] note that the application of management to improve organizational guidelines is a work discipline. Resource management because, according to him, the greater the discipline of workers, the higher the job efficiency that can be achieved. Without good management on the part of workers, it is impossible for an organization to produce maximum performance.

The factors that affect discipline are as follows: 1) the size of the compensation; 2) whether there is outstanding leadership in the organization; 3) whether there are consistent guidelines that can be used as guidance; 4) the courage of leaders to make decisions; 5) whether or not there is oversight of the leadership; 6) whether or not there is concern for employees; 7) behaviors that help the decision-making process. Indicators of work discipline according to Hasibuan [20] are as follows: 1) Goals and Capabilities; 2) Leadership Model; 3) Remuneration; 4) Justice; 5) Waskat or attached supervision; 6) Penalties; 7) Firmness; 8) Human Relations.

\section{METHODS}

This analysis is a quantitative research study utilizing quantitative descriptive methods. As Sugiyono [21] argues, the research method is a scientific way of collecting data for particular purposes and uses. The scientific method means that research practices are based on scientific characteristics, namely logical, analytical and systematic. This study is determinative since it explores the influence, in part, between a number of research variables, namely the key variable leadership and work discipline and the performance of teachers. In this study, a correlation and regression analysis are used.

The population in this study were all 67 teachers of SMA PGRI 2 Palembang. Arikunto [22] says if the subject is less than 100 then it is better to take all samples. If the number of subjects is more than 100 then a sample of between $10 \%-15 \%$ or $20 \%-25 \%$ can be taken. Since the subjects in this study were less than 100 and only amounted to 67 teachers, in this study the sample used was all 67 teachers.

Testing to assess the validity and reliability of the questionnaire using the SPSS application software version 20.0 computer equipment.

Data collection techniques are the most strategic phase in research, since the main objective of research is to acquire data [21]. Data collection methods used in 
this study include reporting techniques, interviews and questionnaires/questions.

\section{RESULTS AND DISCUSSION}

\section{a. Hypothesis Testing 1}

This $\mathrm{R}$ correlation test was performed to assess if there was a relationship between the Principal
When conducting the research, there are many challenges that occur. In addition to barriers, there are also expectations that can be made to address these barriers. In the table 1 , the limitations and anticipation of the challenges faced can be seen.

Leadership variable and the Teacher Performance variable.

Table 1. Correlation and Determination Test Principal Leadership

Model R R Square Adjusted R Square Std. Error of the Estimate

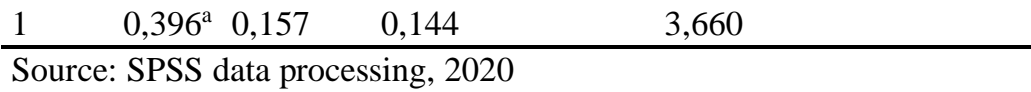

The results of testing the correlation between Principal Leadership and Teacher Performance from the table above, we can know: 1) the correlation coefficient $\mathrm{R}$ is 0.396 , which means that the relationship between Principal Leadership $\left(\mathrm{X}_{1}\right)$ and Teacher Performance $(\mathrm{Y})$ is included in the low category because the correlation value is between $0.20-0.399 ; 2)$ the value of $R^{2}(R$ Square) $=0.157$ which means that $15.7 \%$ of the Principal Leadership variable affects teacher performance while the remaining (100-15.7) $84.3 \%$ is influenced by other factors not examined in this study such as communication, work skills, motivation and other; 3) standard deviation value or Standard Error of Estimate which is used to measure the variation or predicted value. The standard deviation value of the Principal Leadership variable is 3,660, which means that the smaller the standard deviation value or Standard Error of Estimate, the better the model will be, and 4) this test is carried out using the T-test. T-test was conducted to analyze the significance level of the influence of the Principal Leadership variable on teacher performance. Significant tests were carried out using the help of the SPSS version 20.0 program.

Table 2. Significant Test Results (T-Test)

\begin{tabular}{llllll}
\hline \multicolumn{1}{c}{ Model } & \multicolumn{2}{l}{$\begin{array}{l}\text { Unstandardized } \\
\text { Coefficients }\end{array}$} & $\begin{array}{l}\text { Standardized } \\
\text { Coefficients }\end{array}$ & t & Sig. \\
\cline { 2 - 4 } & $B$ & Std. Error & Beta & & \\
\hline \multicolumn{1}{c}{ (Constant) } & 51,830 & 5,911 & & 8,768 & 0,000 \\
1 Principal & 0,290 & 0,083 & 0,396 & 3,480 & 0,001 \\
\hline Leadership & & & & & \\
\hline
\end{tabular}

Source: SPSS data processing, 2020

The results of the significance test (t-test) in the table above at the level of 0.05 obtained the results of the $t$ statistical value test of the Principal Leadership variable of 6.480 . From the results of the $t$ test above, it is known that the value and table of $=2,000$ means that the value of $t$ count $>t$ table which means that Hal is accepted and Hol is rejected. Thus, the first hypothesis in this study states that there is a positive and significant influence between the Principal Leadership on Teacher Performance at SMA PGRI 2 Palembang.

The table above shows that the constant value of the regression equation is $\mathrm{a}=51.830$ and the coefficient value of the independent variable is $b=0.290$, so the regression equation is obtained as follows.

$$
\begin{aligned}
& Y=a+b x \\
& Y=51,830+0,290 X_{1} \\
& Y=0,290 X_{1}+51,830
\end{aligned}
$$

This equation indicates a regression coefficient of 0.290. The findings showed that the leadership of the Principal had a positive and important impact on the success of the teacher. The findings of this study support the hypothesis that the leadership of the Principal has a positive and important influence on the success of teachers. 


\section{b. Hypothesis Testing 2}

Table 3. Correlation and Determination Test Work Discipline

\begin{tabular}{ccccc}
\hline Model & $R$ & $\begin{array}{c}R \\
\text { Square }\end{array}$ & $\begin{array}{c}\text { Adjusted } R \\
\text { Square }\end{array}$ & $\begin{array}{c}\text { Std. Error of the } \\
\text { Estimate }\end{array}$ \\
\hline & & & & \\
1 & $0,585^{\mathrm{a}}$ & 0,342 &, 332 & 3,235 \\
\hline
\end{tabular}

Source: SPSS data processing, 2020

The effects of evaluating the connection between Job Discipline and Teacher Output from the above table can be seen as follows: 1) the correlation coefficient $\mathrm{R}$ is 0.585 , which means that the relationship between Job Discipline $\left(\mathrm{X}_{2}\right)$ and Teacher Success $(\mathrm{Y})$ is included in the Medium group as the correlation value is between $0.40-0.599 ; 2)$ the value of $R_{2}(R$ Square $)=0.342$ which means that 34.2 per cent of the Job Discipline variable influences Teacher Performance while the remaining (100-34.2) $65.8 \%$ is affected by other variables not included in this analysis, such as communication, work capacity, motivation and others: 3) Standard Deviation
Value or Standard Estimate Error used to calculate variance or expected value. The standard deviation value of the Work Discipline variable is 3,235, which means that the lower the standard deviation value or Standard Estimate Error, the better the model will be, and 4) this test shall be carried out using the T-test. The T-test was performed to assess the importance of the effect of the Work Discipline variable on the output of teachers. Important experiments were carried out using the SPSS version 20.0 software. The results of the study test can be found in the table below.

Table 4. Significant Test Results (T-Test) Work Discipline

\begin{tabular}{|c|c|c|c|c|c|}
\hline \multirow[t]{2}{*}{ Model } & \multicolumn{2}{|c|}{$\begin{array}{l}\text { Unstandardized } \\
\text { Coefficients }\end{array}$} & \multirow{2}{*}{$\begin{array}{l}\text { Standardized } \\
\text { Coefficients } \\
\text { Beta }\end{array}$} & \multirow[t]{2}{*}{$\mathrm{t}$} & \multirow[t]{2}{*}{ Sig. } \\
\hline & B & Std. Error & & & \\
\hline$($ Constant) & 35,910 & 6,285 & & 5,714 & 0,000 \\
\hline $\begin{array}{ll}1 & \text { Work } \\
\text { Discipline }\end{array}$ & 0,505 & 0,087 & 0,585 & 5,808 & 0,000 \\
\hline
\end{tabular}

Source: SPSS data processing, 2020

The results of the significance test (t-test) at level 0.05 in the table above, the results of the t-count statistical value of the Work Discipline component are 5.808. From the results of the above test, it is established that the value of $\mathrm{t}$ count is $=5.808$ and the $\mathrm{t}$ table is $=2.000$, which means the value of tcount $>t$ table, which means that $\mathrm{Ha} 2$ is accepted and $\mathrm{Ho} 2$ is rejected. Thus, the second hypothesis in this study indicates that there is a positive and important effect between the Work Discipline on Teacher Performance at SMA PGRI 2 Palembang.

The table above shows that the constant value of the regression equation is $\mathrm{a}=51.830$ and the coefficient value of the independent variable is $b=0.290$, so the regression equation is obtained as follows.

$$
\mathrm{Y}=\mathrm{a}+\mathrm{bx}
$$

$$
\begin{aligned}
& Y=35,910+0,505 X_{1} \\
& Y=0,505 X_{1}+35,910
\end{aligned}
$$

This equation indicates a regression coefficient of 0.505 .

The findings of the study show that job motivation has a positive and important influence on the performance of teachers. The findings of this study support the hypothesis that work discipline has a positive and important impact on the performance of teachers.

\section{c. Hypothesis Testing 2}

This correlation test was conducted to determine whether the regression coefficient had a positive and significant relationship or not jointly between the Principal Leadership and Work Discipline variables on the Teacher Performance of SMA PGRI 2 Palembang. 
Table 5. Correlation and Determination Test Principal Leadership and Work Discipline Model Summary ${ }^{b}$

\begin{tabular}{lllll}
\hline Model & $\mathrm{R}$ & $\mathrm{R}$ & $\begin{array}{l}\text { Adjusted R } \\
\text { Square }\end{array}$ & $\begin{array}{l}\text { Std. Error of the } \\
\text { Estimate }\end{array}$ \\
\hline & & & \\
1 & $0,662^{\mathrm{a}}$ & 0,439 & 0,421 & 3,010 \\
\hline \multicolumn{2}{l}{ Source: SPSS data processing, 2020}
\end{tabular}

The results of testing the correlation between Principal Leadership and Work Discipline on Teacher Performance from the table above, we can know as follows; 1) the findings of the correlation test between Principal Leadership and Work Discipline on Teacher Performance from the table above indicate that the correlation coefficient $\mathrm{R}$ is 0.662 , which means that the relationship between Principal Leadership and Work Discipline on Teacher Performance is included in the Strong group since the multiple correlation value is between $0.60-0.799 ; 2$ ) The value of R2 (R Square) = 0.439 , which means that 43.9 per cent of the Principal Leadership and Work Discipline variables impact the performance of teachers, while the remaining 56.1 per cent (100-43.9) are affected by other factors not included in the analysis. It's like communication, job skills, inspiration, and so on; 3) the standard deviation of the Principal Leadership and Job Discipline variable is 3.010 , which means that the lower the standard deviation or Standard Estimate Error, the better the model would be, and 4) this test shall be carried out using the T-test. The T-test was performed to assess the importance of the impact of the principal's leadership variables and the work discipline together on teacher performance. Important experiments were carried out using the SPSS version 20.0 software.

Testing of multiple correlation coefficient analysis between Principal Leadership and Work Discipline variables for teacher performance with the following parameters. If the value of $F$ count $>F$ Table means that $\mathrm{Ha} 3$ is accepted and vice versa $\mathrm{Ho} 3$ is rejected if $\mathrm{F}$ count $<\mathrm{F}$ table is accepted. This important test was carried out with the aid of the SPSS version 20.0 program. The results of the study can be found in the table below.

Table 6. Multiple Regression Test Results (F-Test)

\begin{tabular}{ccccccc}
\multicolumn{8}{c}{ ANOVA $^{\text {a }}$} \\
\hline \multirow{2}{*}{ Model } & $\begin{array}{c}\text { Sum of } \\
\text { Squares }\end{array}$ & df & $\begin{array}{c}\text { Mean } \\
\text { Square }\end{array}$ & F & Sig. \\
& Regression & 453,395 & 2 & 226,697 & 25,027 & $0,000^{\mathrm{b}}$ \\
\multirow{2}{*}{1} & Residual & 579,710 & 64 & 9,058 & & \\
& Total & 1033,104 & 66 & & & \\
\hline
\end{tabular}

Important test results in the table above at a significant value of 0.05 obtained the test results for the statistical value of $\mathrm{F}$ count of 25.027 and the value of $\mathrm{F}$ table, which means that the value of $F$ count $>F$ table which means that $\mathrm{Ha} 3$ is accepted and vice versa $\mathrm{Ho} 3$ is rejected. Thus, the third hypothesis in this study indicates that there is a positive and important effect on the teaching output of SMA PGRI 2 Palembang between the main leadership variable and the work discipline.

The constant value of the regression equation $\mathrm{a}=$ 25.027 and the coefficient value of the independent variables $b 1=0.231$ and $b 2=0.464$ are derived from the data in the table above, and the regression equation is obtained as follows.
From this equation, the regression coefficient $X_{1}$ value of 0.231 is shown, which means that the Principal Leadership value increases by one unit, the Teacher Performance value increases by 0.231 units, assuming that $\mathrm{X}_{2}$ is fixed, as well as the regression coefficient $\mathrm{X}_{2}$ for the job discipline by 0.464 , increasing by one unit, and then Teacher Performance increases.

\section{CONCLUSION}

Based on the research results, it can be concluded as follows: 1). there is a positive and significant influence of principal leadership on the teacher performance of SMA PGRI 2 Palembang; 2) there is a positive and significant effect of work discipline on the teacher performance of SMA PGRI 2 Palembang, and 3) there is a positive and significant influence on the leadership 
of the principal and work discipline together on the teacher performance of SMA PGRI 2 Palembang.

\section{AUTHORS' CONTRIBUTION}

Deslihanida: designed and performed experiments and analysed data. Yasir Arafat and Yenny Puspita: Proofing and Correcting.

\section{ACKNOWLEDGMENTS}

Our deepest gratitude goes to Teachers SMA PGRI 2 Palembang, Chancellor of Palembang PGRI University, Director of the Postgraduate Program of PGRI Palembang University and the Education Management Study Program of PGRI Palembang University, who have supported us in doing this extraordinary thing. This project is funded independently. We also want to thank our Education Management friends who helped us a lot in a short time frame to complete this project.

\section{REFERENCES}

[1] Mulyasa, E. (2004). Menjadi Kepala Sekolah Profesional Dalam Konteks Menyukseskan MBS dan KBK. Bandung: PT. Remaja Rosda Karya.

[2] Yuliana. (2015). Kepemimpinan Kepala Sekolah Dalam Meningkatkan Profesionalisme Guru di SMA Negeri 1 Mempawah Hilir . https://www.ejurnal.com/2015/01/kepemimpinan-kepalasekolah-dalam_4.html.

[3] Ohide., \& Mbogo. (2017). The Influence of School Leadership on Teachers Job Satisfaction and Performance in Private School in Yei Town South Sudan. European Journal of Training and Development Studies Vol.4 No.3, pp.25-33, August 2017. Online.

[4] Emmanouil, K. D. (2014). The Impact of Leadership on Teachers' Effectiveness. International Journal of Humanities and Social Science Vol. 4, No. 7(1); May 2014. Online.

[5] Susanti., Harapan E., Wardiah,D. (2019). The Effect of Madrasah Head Leadership Style and Work Motivation on Work Discipline of Madrasah Aliyah Teachers. Jurnal Ilmiah Ilmu Administrasi Publik: Jurnal Pemikiran dan Penelitian Administrasi Publik Volume 9 Number 1, January - June 2019. Page 1-8. Online.

[6] Ruslan, Lian,B., Fitriani,Y. (2020). The Influence of Principal's Situational Leadership and Teacher's Professionalism on Teacher's Performance. International Journal of Progressive Sciences and Technologies (IJPSAT) ISSN: 25090119. (C) 2020 International Journals of Sciences and High Technologies Vol. 20 No. 1 April 2020, pp. 135-143. Online.

[7] Herry., Lian,B., Fitriani,Y. (2020). Pengaruh Kepemimpinan Kepala Sekolah dan Komitmen Guru terhadap Kinerja Profesional Guru. Jurnal Pendidikan Tambusai. Halaman 1658-1666 Volume 4 Nomor 2 Tahun 2020 Online.

[8] Perawati. Lian, B.,Tobari. (2018). The Influence of Compensation, Work Motivation and Discipline on Teacher's Work Productivity. European Journal of Education Studies.

[9] Kartini, D., Kristiawan, M., \& Fitria, H. (2020). The Influence of Principal's Leadership, Academic Supervision, and Professional Competence toward Teachers' Performance. Education and Training for Strengthening Principal to Effective Schools. International Journal of Progressive Sciences and Technologies (IJPSAT), 20(1).

[10] Asvio, N., Yamin, M., \& Risnita. (2019). Influence of Leadership Style, Emotional Intelligence and Job Satisfaction toward Organizational Commitment (Survey at SMA Muhammadiyah South Sumatera). International Journal of Scientific \& Technology Research 8 (8).

[11] Mitriani. (2005). Manajemen Sumber Daya Manusia Berdasarkan Kompetensi, terjemahan[Human Resource Management Based on Competence, translation]. Jakarta: Pustaka Utama Grafiti.

[12] Suwarni. (2017). Pengaruh Gaya Kepemimpinan Kepala Sekolah Terhadap Kinerja Guru Ekonomi [The Effect of Principal's Leadership Style on Economic Teacher Performance]. Jurnal Pendidikan dan Pembelajaran Vol 18 No 2, Oktober.

[13] Khasanah, U., Kristiawan, M., \& Tobari. (2019). The Implementation of Principals' Academic Supervision in Improving Teachers' Professionalism in the State Primary Schools. International Journal of Scientific \& Technology Research, 8(8).

[14] Hanim, H., \& Rahmadoni, J. (2020). Determination of Lecturer Reception Using Analytical Hierarchy Process (AHP). Journal of Applied Engineering and Technological Science (JAETS), 1 (2), 136-141.

[15] Nugroho, A.R., dkk. (2016). Pengaruh Komitmen Organisasi, Motivasi Berprestasi dan Gaya Kepemimpinan Terhadap Kinerja Karyawan PT. Wangsa Jatra Lestari [The Effect of Organizational Commitment, Achievement Motivation and 
Leadership Style on Employee Performance of PT. Wangsa Jatra Lestari]. Jurnal Bisnis dan Ekonomi. September 2016, hal 194-203 Vol.23. No.2.

[16] Supardi. (2014). Kinerja Guru [Teacher Performance]. Jakarta: PT. Grafindo Persada.

[17] Uno, B. H., \& Lamatenggo, N. (2012). Teori Kinerja dan Pengukurannya [Performance Theory and Its Measurement]. Jakarta: Bumi Aksara

[18] Paruru, J. D. (2016). Pengaruh Disiplin Kerja dan Kemampuan Kerja Terhadap Kinerja Karyawan PT. Air Manado [The Effect of Work Discipline and Work Ability on Employee Performance at PT. Air Manado]. Jurnal EMBA Vol.5 No.1 Hal.225-233.

[19] Jeffrey, I., Soleman, M. (2017). The Effect of Work Discipline, Achievement Motivation and Career Path Toward Employee Performance of The National Resiliencenstitute of The Republic of Indonesia. Jurnal International IJAIEM Vol.6 Issue 8, August.

[20] Hasibuan, M. (2012). Manajemen Sumber Daya Manusia [Human Resource Management]. Jakarta: Bumi Aksara.

[21] Sugiyono. (2014). Metode Penelitian Kuantitatif kualitatif dan $R \& D$ [Qualitative Quantitative Research Methods and $R$ \& D]. Bandung: Alfabetha.

[22] Arikunto, S. (2009). Dasar-Dasar Evaluasi Pendidikan [Basics of Educational Evaluation]. Jakarta: Bumi Aksara 